\title{
APLIKASI TEKNOLOGI NANOKOMPOSIT LIMBAH PADAT PETERNAKAN SAPI (LPPS) DI INDUSTRI GERABAH DESA BANYUMULEK KABUPATEN LOMBOK BARAT
}

\section{APPLICATION OF NANOCOMPOSITE TECHNOLOGY BASED SOLID COW MANURE WASTE FOR POTTERY INDUSTRY IN BANYUMULEK VILLAGE WEST LOMBOK DISTRICT}

\author{
Saprini Hamdiani ${ }^{1}$, Ulul Khairi Zuryati ${ }^{1}$, Suthami Ariessaputra ${ }^{2}$ \\ ${ }^{1}$ Program Studi Kimia, Fakultas Matematika dan Ilmu Pengetahuan Alam Universitas Mataram \\ ${ }^{2}$ Jurusan Teknik Elektro, Fakultas Teknik Universitas Mataram \\ Email : saprini.h@unram.ac.id
}

Diterima: 2 Agustus 2017. Disetujui 2 Agustus 2017. Dipublikasikan: 30 September 2017

\begin{abstract}
Abstrak. Desa Banyumulek Kabupaten Lombok Barat adalah sentra industri gerabah terbesar di Provinsi NTB sejak tahun 1960-an. Gerabah dari Desa Banyumulek bahkan telah mampu menembus pasar ekspor ke beberapa negara Eropa dan Australia. Perkembangan industri gerabah yang semakin positif, tidak didukung oleh ketersediaan bahan baku pembuatan gerabah. Salah satu bahan baku utama pembuatan gerabah yaitu pasir semakin mahal harganya. Penggunaan pasir dapat digantikan oleh limbah padat peternakan sapi (LPPS). Limbah padat peternakan sapi mengandung selulosa yang tinggi sehingga efektif sebagai filler penguat tanah berlempung berdasarkan konsep teknologi nanokomposit. Kandungan silikat pada limbah padat peternakan sapi juga dapat meningkatkan plastisitas tanah berlempung, sehingga gerabah yang dibuat semakin mudah dibentuk. Selain itu, kandungan C-organik yang tinggi akan mengurangi bobot gerabah yang dibuat sampai $24,5 \%$. Limbah padat peternakan sapi sangat potensial diaplikasikan pada industri gerabah karena ketersediaannya yang sangat melimpah di Provinsi NTB yang terkenal sebagai Bumi Sejuta Sapi (BSS). Oleh karena itu, melalui kegiatan Ipteks Bagi Masyarakat (IbM) dilakukan kegiatan sosialisasi dan praktek pengolahan limbah padat peternakan sapi kepada para pengrajin gerabah. Produk dari kegiatan ini adalah gerabah yang kuat dan ringan, dengan bahan baku alternatif yang ramah lingkungan.
\end{abstract}

Kata kunci : Gerabah, Nanokomposit, Limbah Padat Peternakan Sapi, Banyumulek, Lombok Barat

\begin{abstract}
Banyumulek village, West Lombok regency is the largest center of pottery industry in West Nusa Tenggara Province since 1960s. Pottery from Banyumulek had entered the export markets to several European countries and Australia. However, the positive development of pottery industry is not supported by the availability of raw materials for pottery production. One of the main raw materials for pottery production is sand, the more expensive the price. Solid cow manure waste is able to replace the sand. This solid waste contains high cellulose so that it acts effectively as a filler of clay soil amplifier based on the concept of nanocomposite technology. The silicate content in this solid waste also increases the plasticity of the clay so that the pottery becomes easily formed. In addition, a high carbon-organic content will reduce the weight of pottery up to $24.5 \%$. Moreover, solid cow manure waste is potentially applied to the pottery industry due to its abundant availability in NTB Province. Therefore, Science and Technology Program for Community have been conducted at Banyumulek village. This program consists of several steps including socialization and training for pottery production based on solid cow manure waste. The products obtained are strong and lightweight pottery, with environmentally friendly raw materials.
\end{abstract}

Keywords: Pottery, Nanocomposite, Cow Manure Solid Waste, Banyumulek, West Lombok.

\section{PENDAHULUAN}

Desa Banyumulek Kecamatan Kediri, Kabupaten Lombok Barat adalah sentra industri gerabah terbesar di Propinsi NTB [1]. Potensi alam yg besar dengan tersedianya lempung berkualitas baik serta keahlian masyarakat dalam mengolah lempung menjadi berbagai jenis dan model gerabah mendukung perkembangan industri gerabah sejak tahun 1960an hingga saat ini. Terdapat 2.227 Usaha Mikro Kecil Menengah (UMKM) di Kecamatan Kediri [2] dan hampir $80 \%$ diantaranya merupakan UMKM gerabah yang berlokasi di Desa Banyumulek.

Industri gerabah di Desa Banyumulek tumbuh dan berkembang menjadi sumber penghasilan utama $80 \%$ warga desa sehingga sangat potensial bagi pengembangan sektor ekonomi kreatif yang mendukung peningkatan kesejahteraan masyarakat. Namun masih banyak kendala yang harus dihadapi pengrajin gerabah, antara lain: proses produksi yang masih sangat sederhana dan ketersediaan bahan baku.

Salah satu bahan baku utama pembuatan gerabah yaitu pasir harganya terus meningkat 
seiring dengan perkembangan pembangunan infrastruktur. Hal ini membuat para pengrajin kesulitan memperoleh bahan baku. Dalam pembuatan gerabah di Banyumulek pasir digunakan sebagai penguat (filler) bagi tanah liat, kandungan unsur silika pada pasir akan meningkatkan sifat plastisitas tanah liat sehingga mudah dibentuk [3]. Oleh karena itu, sangat perlu dicari alternatif bahan pengganti pasir.

Salah satu solusi yang ditawarkan adalah penggunaan penggunaan teknologi nanokomposit berbasis limbah padat peternakan sapi (LPPS). Sapi adalah salah satu komoditas ternak strategis dengan populasi yang terbesar di daerah NTB yang terkenal dengan Bumi Sejuta Sapi (BSS). Jumlah ternak sapi lebih dari satu juta ekor diseluruh wilayah NTB [4]. Jika 1 ekor sapi menghasilkan $20 \mathrm{~kg}$ kotoran/hari, maka tersedia bahan baku sejumlah 160 ton/hari. Ini artinya ketersediaan limbah padat peternakan sapi sangat melimpah di Provinsi NTB.

Limbah padat peternakan sapi mengandung selulosa 25,2\% [5]. Selulosa sangat potensial untuk memperkuat struktur polimer nanokomposit selulosa-lempung [6]. Kadar unsur silika sekitar 9,6\% pada kotoran sapi, membuat gerabah memiliki struktur yang kuat dan tidak mudah pecah terhadap suhu pembakaran yang tinggi $\left(9500-11500^{\circ} \mathrm{C}\right)$ [7]. Selain itu kandungan karbon organik yang tinggi pada limbah padat peternakan sapi akan membuat gerabah yang dihasilkan lebih ringan dibandingkan dengan gerabah pasir.

Teknologi nanokomposit limbah padat peternakan sapi adalah salah satu teknologi yang murah, mudah dan sangat cocok untuk diaplikasikan pada gerabah. Oleh karena itu, dalam kegiatan ini dilakukan sosialisasi dan pelatihan pengolahan limbah padat peternakan sapi serta teknik mekanisasi proses produksi kepada para pengrajin. Melalui kegiatan ini, diharapkan dapat menghasilkan gerabah yang berkualitas, tidak mudah pecah dan lebih ringan.

\section{METODE KEGIATAN}

Program pengabdian kepada masyarakat ini bekerjasama dengan dua mitra, yaitu UMKM Patuh Pacu dan UMKM Pade Angen Desa Banyumulek Kecamatan Kediri Lombok Barat. Kedua mitra berperan aktif dalam setiap kegiatan.

Metode pelaksanaan kegiatan meliputi : perencanaan, pelatihan, observasi dan evaluasi, dan refleksi [8]. Kegiatan-kegiatan yang dilakukan pada tahap perencanaan adalah: 1) Survey lokasi kegiatan, 2) Sosialisasi program IbM pada kedua mitra dan 3) Penyusunan program pelatihan.
Kegiatan Pelatihan meliputi: 1) Mekanisasi proses produksi dengan penggunaan mesin pengiling tanah. 2) Pelatihan pengolahan limbah padat peternakan sapi. Limbah peternakan sapi diolah dengan proses fermentasi selama 3-4 minggu sampai bau khas kotoran hilang dan berubah warna menjadi lebih gelap. 3) Pelatihan penggunaan hasil fermentasi limbah padat peternakan sapi pada gerabah. 4) Pembuatan design produk dan kemasan serta 5) Promosi produk pada berbagai media sosial dan pameran.

\section{HASIL DAN PEMBAHASAN}

Tahapan kegiatan yang telah dilaksanakan adalah sebagai berikut:

\section{Sosialisasi program IbM kepada pengrajin gerabah}

Kegiatan sosialisasi dilaksanakan dengan mengundang para pengrajin anggota UMKM Patuh Pacu dan Pade Angen. Sosialisasi berisi penjelasan tentang proses pengolahan limbah padat peternakan sapi, dampak negatif limbah peternakan sapi yang tidak diolah bagi lingkungan dan kesehatan, serta nilai ekonomis pengolahan limbah padat peternakan sapi.

\section{Praktek pengolahan limbah padat peternakan sapi}

Kegiatan ini bertujuan untuk meningkatkan pemahaman pengrajin gerabah untuk mengolah limbah peternakan sapi sebagai bahan baku utama pembuatan gerabah pengganti pasir. Limbah difermentasi menggunakan campuran EM4 dan gula pasir sampai tidak berbau, bertekstur seperti tanah dan berwarna gelap. Tahap awal proses fermentasi dilakukan dengan media polybag besar. Penggunaan media polybag bertujuan untuk memudahkan proses pemindahan dan melindungi hasil fermentasi dari air hujan. Proses fermentasi berlangsung selama 3-4 minggu.

\section{Aplikasi hasil fermentasi limbah peternakan sapi pada gerabah}

Hasil fermentasi limbah peternakan sapi yang telah diperoleh pada tahap 2, kemudian diaplikasikan sebagai bahan campuran gerabah berdasarkan konsep teknologi nanokomposit. Perbandingan tanah liat dengan hasil fermentasi adalah 1:1/2 tanpa campuran pasir. Hasil gerabah nanokomposit lebih ringan. Hasil uji berat dari beberapa model gerabah ditunjukkan pada Tabel 1 . 
Tabel 1. Hasil uji berat gerabah

\begin{tabular}{llccc}
\hline No & Model & Ukuran Gerabah & Gerabah Pasir $(\mathrm{Kg})$ & Gerabah LPPS $(\mathrm{kg})$ \\
\hline 1 & Panset & 80 & 11,00 & 7,80 \\
2 & Perunggu & 80 & 7,50 & 5,20 \\
3 & Spanyol (bowling) & 80 & 7,60 & 5,20 \\
4 & Sprite & 80 & 2,80 & 2,20 \\
5 & Spanyol & 80 & 4,50 & 3,70 \\
\hline
\end{tabular}

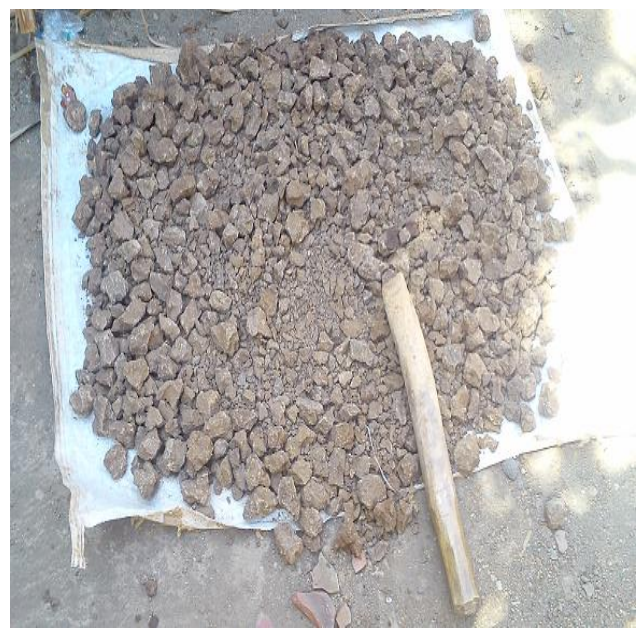

(a)

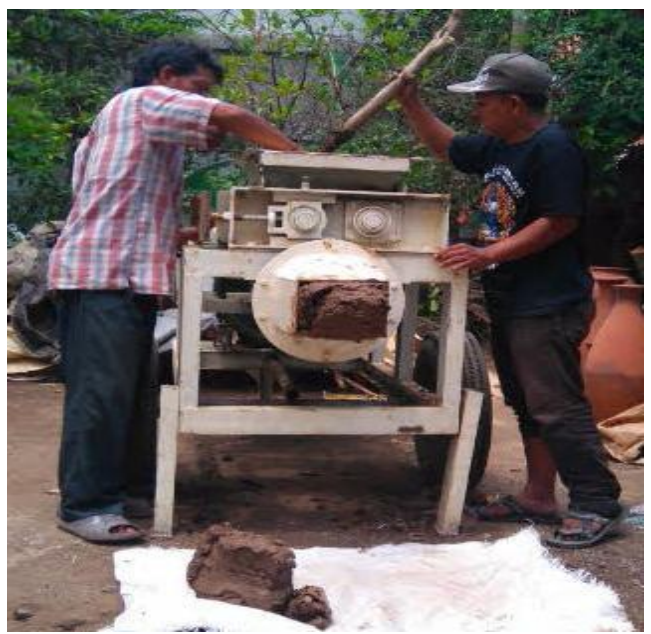

(b)

Gambar 1. (a) alat penumbuk sederhana, (b) Penggunaan mesin penggiling tanah

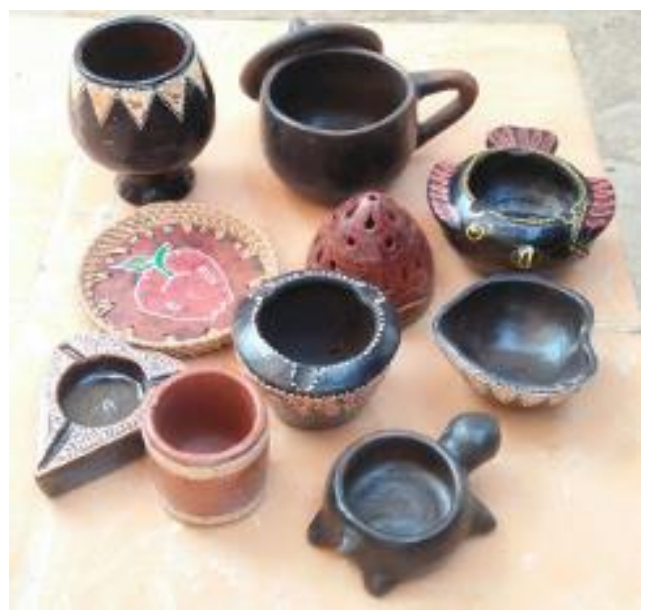

Gambar 2. Design produk

Berdasarkan Tabel 1, terlihat bahwa penggunaan hasil fermentasi limbah peternakan sapi dapat mengurangi berat gerabah sehingga gerabah yang dihasilkan lebih ringan. Fakta ini membuat pengraji semakin tertarik untuk mengaplikasikan teknologi nanokomposit pada gerabah

\section{Mekanisasi proses pembuatan gerabah dengan menggunakan mesin penggiling tanah}

Selama ini pengrajin gerabah di Desa Banyumulek menggunakan alat penumbuk sederhana untuk menghaluskan tanah liat.
Penggunaan alat ini sangat tidak efisien waktu dan biaya. Dalam kegiatan ini diperkenalkan penggunaan mesin penggiling untuk meningkatkan kapasitas dan mempercepat proses produksi. Mesin penggiling bekerja menggunakan mesin diesel 16 Hp dengan kapasitas hingga $200 \mathrm{~kg}$ tanah liat/jam. Penggunaan mesin penggiling tanah dan alat penumbuk sederhana diperlihatkan pada Gambar 1.

\section{Desain produk dan kemasan}

Dalam kegiatan ini, Tim pelaksana berkoordinasi dengan pengrajin dan teknisi design 
grafis untuk menentukan design dan kemasan gerabah. Hasil dari kegiatan ini menghasilkan memberikan nama / brand baru bagi gerabah yang dihasilkan yaitu GAKOSHI (Gerabah berteknologi nanokomposit/Gerabah Kotoran Sapi). Produk Gakoshi di design khas dengan warna hitam, seperti warna limbah padat peternakan sapi hasil fermentasi.

\section{Promosi melalui media sosial dan pameran}

Produk Gakoshi yang telah dikemas dipromosikan melalui berbagai media sosial seperti facebook dan instagram. Para pengguna media sosial sangat positif merespons adanya produk GAKOSHI. Media sosial sangat potensial sebagai media promosi produk yang murah dan cepat tersebar luas. Produk GAKOSHI juga telah dipamerkan di China dalam ajang pameran budaya oleh Pemerintah Provinsi NTB pada Bulan September 2017.

\section{Promosi dan penjualan Produk melalui showroom gerabah}

Produk Gakoshi dipamerkan di Koperasi Taman Geopark Rinjani dan di Desa Sade Kabupaten Lombok Tengah. Desa tradisional Sade terkenal bahkan mendunia karena penggunaan limbah padat peternakan sapi untuk membersihkan lantai rumah. Isu ini diangkat oleh tim pengabdian, karena produk gerabah yang dibuat sama-sama memanfaatkan limbah padat peternakan sapi.

\section{KESIMPULAN}

Telah dilakukan sosialisasi dan praktik pengolahan limbah padat peternakan sapi sebagai bahan campuran gerabah berdasarkan konsep teknologi nanokomposit. Respon masyarakat sangat baik dan aktif selama pelaksanaan kegiatan. Hasil akhir dari kegiatan diperoleh produk gerabah yang ringan dan ramah lingkungan dengan pemanfaatan limbah. Produk pengabdian diharapkan dapat menjadi alternatif solusi untuk mengatasi berbagai kendala pengembangan industri gerabah di Desa Banyumulek Kabupaten Lombok Barat.

\section{UCAPAN TERIMAKASIH}

Ucapan terimakasih disampaikan kepada pihak IPTEKDALIPI yang telah menginisiasi penelitian gerabah nanokomposit pada Tahun 2016. Serta kepada DP2M KEMENRISTEK-DIKTI yang telah memberikan dana kegiatan pengabdian kepada masyarakat pada tahun 2017 melalui skim Ipteks bagi Masyarakat (IbM). Ucapan yang sama disampaikan kepada para pengrajin gerabah UMKM Patuh Pacu dan Pade Angen Desa Banyumulek Kecamatan Kediri Kabupaten Lombok Barat.

\section{DAFTAR PUSTAKA}

[1] Sentra industri kerajinan gerabah di Desa Banyumulek, Available at :http://www.wisatadilombok.com/2013/06/sent ra-industri-kerajinan-gerabah-di.html

[2] Lombok Barat Dalam Angka 2014., Badan Pusat Statistik Kabupaten Lombok Barat.

[3] Ana S. Abreu, M. Oliveira, A.V. Machado, 2014., Effect of clay mineral addition on properties of bio-based polymer blends., Applied Clay Science 104, 277-285, 2015

[4] Data Hewan Peternakan Provinsi NTB Tahun 2014., Dinas Peternakan dan Kesehatan Hewan Provinsi NTB.

[5] Sihotang, B. 2010. "Kandungan Senyawa Kimia Pada Pupuk Kandang Berdasarkan Jenis Binatangnya".

[6] C.D. Delhom, L.A. White-Ghoorahoo, S.S. Pang, Development and characterization of cellulose/clay nanocomposites., Composites: Part B 41, 475-481, 2010

[7] Chazali., Granik-Gerabah Organik., available at: http://ramp.ipb.ac.id/alumni/detail/4.,

[8] Dick, W., Carey, L., \& Carey, J. O. The Systematic Design Of Instruction. USA: Addison-Wesley Educational Publisher Inc. 2001. 